Western North American Naturalist 74(4), (C) 2014, pp. 467-471

\title{
CURRENT DISTRIBUTIONAL STATUS OF THE STRIPED SKUNK, MEPHITIS MEPHITIS, IN BAJA CALIFORNIA, MEXICO
}

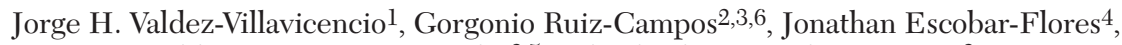 \\ Aldo A. Guevara-Carrizales 3,5 and Salvador González-Guzmán ${ }^{3}$
}

\begin{abstract}
AвsтRACT. -We provide information on recent records of the 2 subspecies of striped skunk occurring in the northeastern (Mephitis mephitis estor) and northwestern (M. m. holzneri) region of Baja California, Mexico. Most of the recent records for these subspecies come from valleys and suburban zones.
\end{abstract}

Resumen.-Aportamos registros recientes para las dos subespecies del zorrillo rayado Mephitis mephitis que ocurren en el noreste (M. m. estor) y noroeste (M. m. holzneri) de Baja California, México. La mayoría de los registros recientes de estas subespecies provienen de los valles y zonas suburbanas.

The striped skunk, Mephitis mephitis Schreber, 1776, is a medium-sized mustelid ranging in total length from 520 to $770 \mathrm{~mm}$ and in weight from 1.8 to $4.5 \mathrm{~kg}$ (Feldhamer et al. 2003). It has a triangular head, and the pelage is entirely black with a bifurcate white dorsal stripe that runs from the nose to the tail (Wade-Smith and Verts 1982). The striped skunk is widely distributed in North America and occurs throughout southern Canada, the United States, and northern Mexico (WadeSmith and Verts 1982, Álvarez-Castañeda 2000), primarily at elevations below $1800 \mathrm{~m}$ above sea level (Grinnell et al. 1937, Reid and Helgen 2008), but records extend as high as 4200 $\mathrm{m}$ (Nelson 1930). The species is found commonly in woodlands, brushlands, open fields, rocky outcrops, and riparian habitats (Baker 1956, Wade-Smith and Verts 1982) and can be abundant in agricultural fields (Hamilton and Whitaker 1979). It is opportunistically omnivorous but feeds primarily on insects (Verts 1967, Reid and Helgen 2008).

At least 13 subspecies of Mephitis mephitis have been recognized (Hall 1981, Feldhamer et al. 2003), of which 3 are known to occur in Mexico: M. m. estor in northeastern Baja California, Sonora, Chihuahua, and Durango;
M. m. holzneri in northwestern Baja California (Huey 1964, Alvarez-Castañeda 2000); and M. m. varians in Chihuahua, Coahuila, Nuevo Leon, and Tamaulipas (Hall 1981). The distributions of the 2 subspecies reported for Baja California, however, have not been well documented or updated recently. Mephitis mephitis estor has been reported from only one locality in northeastern Baja California (Pozo de Vicente) on the basis of a single specimen (cf. Alvarez-Castañeda 2000). Since then, no records of the subspecies for Baja California have been published. Mephitis mephitis holzneri was described by Mearns (1897) from a specimen collected at San Isidro Ranch, Lower California (Baja California), near the United States-Mexico border. Huey (1964) commented that the southernmost known occurrence of subspecies holzneri is along the Santo Domingo River just north of San Quintín. Also, Alvarez-Castañeda (2000) pointed out that this subspecies has not actually been collected in Baja California, as the identification of the San Isidro Ranch (= San Ysidro) as located in the territory under Mexican jurisdiction was erroneous.

The 2 subspecies known in Baja California are distinguishable in cranial measurements

\footnotetext{
${ }^{1}$ Conservación de Fauna del Noroeste, A.C., La Paz, Baja California Sur, 23205, México.

${ }^{2}$ Cuerpo Académico Estudios Relativos a la Biodiversidad, Facultad de Ciencias, Universidad Autónoma de Baja California, km. 103 carretera TijuanaEnsenada, Ensenada, Baja California, 22870, México. U.S. mailing address: PMB 064, Box 189003, Coronado, CA 92178-9003.

${ }^{3}$ Laboratorio de Vertebrados, Facultad de Ciencias, Universidad Autónoma de Baja California, km. 103 carretera Tijuana-Ensenada, Ensenada, Baja California, 22870, México.

${ }^{4}$ Centro de Investigaciones Biológicas del Noroeste, Instituto Politécnico Nacional, 195, Playa Palo de Santa Rita Sur, La Paz, Baja California Sur, 23096, México.

5 Instituto de Investigaciones Oceanológicas, Universidad Autónoma de Baja California, km. 103 carretera Tijuana-Ensenada, Ensenada, Baja California, 22870, México.

${ }^{6}$ Corresponding author. E-mail: gruiz@uabc.edu.mx
} 


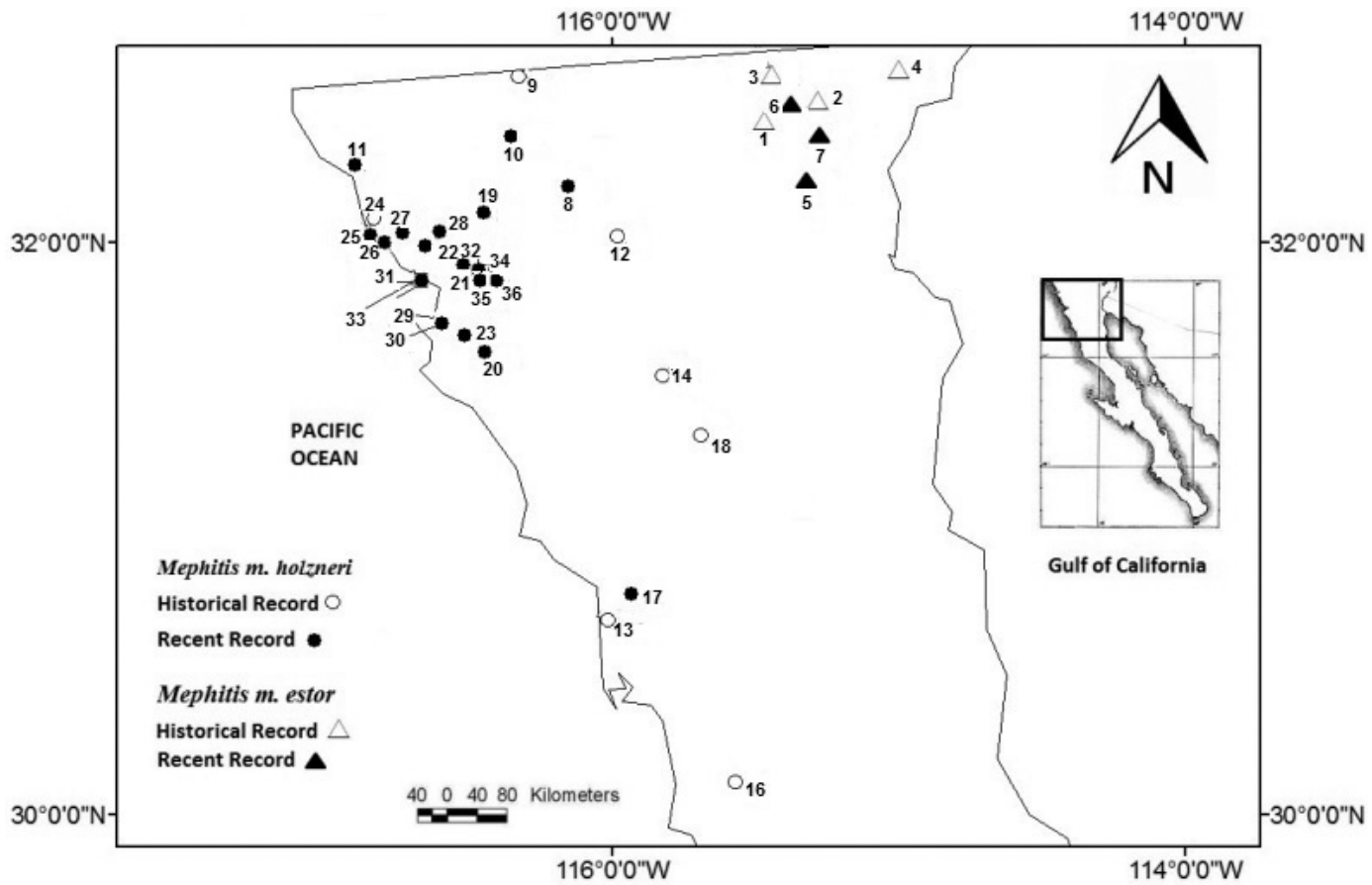

Fig. 1. Records of the 2 subspecies of Mephitis mephitis in Baja California, Mexico. See text for details of localities. The historical records of specimens in U.S. museums were collected between 1896 and 1928. The recent records date from 2000 to 2013.

and pattern of the pelage. Mephitis mephitis estor differs from M. m. holzneri in its smaller body size and broader stripes on the dorsum. Also, the skull of M. m. estor is smaller, with the posterior margin of the palate ending about on a line with the posterior molars, either square or having only a very small notch; and the basilar length of Hensel is $<66 \mathrm{~mm}$ (Howell 1901).

Here we provide new information on records of the 2 subspecies of Mephitis mephitis for Baja California. Our records were based on our own direct observations, photographs, and voucher specimens deposited in the Mammal Collection, Universidad Autónoma de Baja California (UABC), at Ensenada, Baja California, Mexico; other previously unpublished records are based on specimens housed in the following collections: San Diego Natural History Museum (SDNHM), Museum of Vertebrate Zoology (MVZ), and U.S. National Museum of Natural History, Smithsonian Institution (USNM).

We located a total of 54 records of $M$. mephitis (13 of M. m. estor, 41 of M. m. holzneri) from 37 localities in 4 municipalities of the state of Baja California, including voucher specimens (historical and recent) deposited in the museums cited above. The records for each subspecies include the following: locality name followed in brackets by the number keying the location in Fig. 1, geographical coordinates, elevation (when available), sex of specimen, catalog number, and collection date. The records extend temporally from 1896 to 2013.

\section{Mephitis mephitis estor Merriam, 1890}

Municipality of Mexicali-Sierra Cucapah [1], $32.42193^{\circ} \mathrm{N}, 115.46758^{\circ} \mathrm{W}$, male specimen (USNM 137121), 10 April 1905. Calexico, 18 mi SE [2], 32.49274 ${ }^{\circ} \mathrm{N}, 115.281060^{\circ} \mathrm{W}, 13 \mathrm{~m}$ elevation, male specimen (USNM 203128), 1 January 1914. Mexicali, New River, 5 mi SSE [3], 32.60325 $\mathrm{N}, 115.44896^{\circ} \mathrm{W}, 4 \mathrm{~m}$ elevation, male specimen (USNM 210238), 10 November 1913. Alamo River, $20 \mathrm{mi}$ SW Pilot Knob (Imperial County, California) [4], 32.601389 ${ }^{\circ} \mathrm{N}$, $115.00^{\circ} \mathrm{W}, 22 \mathrm{~m}$ elevation, 4 females (MVZ $39041,39044,39046,39047)$ and 3 males 
TABLE 1. Body and cranial measurements of recent voucher specimens of Mephitis mephitis holzneri from Baja California.

\begin{tabular}{|c|c|c|c|c|c|}
\hline & \multicolumn{5}{|c|}{ Catalog number } \\
\hline & $\begin{array}{c}\text { CVUABC } \\
107\end{array}$ & $\begin{array}{c}\text { CVUABC } \\
897^{*}\end{array}$ & $\begin{array}{c}\text { CVUABC } \\
910^{* *}\end{array}$ & $\begin{array}{l}\text { CVUABC } \\
1037 * * *\end{array}$ & $\begin{array}{c}\text { CVUABC } \\
1158\end{array}$ \\
\hline \multicolumn{6}{|l|}{ Body } \\
\hline Sex & Male & & & Female & Female \\
\hline Total length $(\mathrm{mm})$ & 662 & 316 & & & 660 \\
\hline Tail length (mm) & 251 & 115 & & 230 & 286 \\
\hline Ear length (mm) & 25 & 21 & & & 25 \\
\hline Hind foot length (mm) & 71 & 46 & & & 60 \\
\hline Mass $(\mathrm{g})$ & & & & & 1800 \\
\hline \multicolumn{6}{|l|}{ Skull } \\
\hline Basal length (mm) & 64.2 & & 62.2 & & 68.9 \\
\hline Zygomatic breadth (mm) & 44.3 & & 40.9 & & 42.5 \\
\hline Mastoid breadth $(\mathrm{mm})$ & 37.1 & & 34.5 & & 37.3 \\
\hline Breadth across postorbital processes $(\mathrm{mm})$ & 19.9 & & 23.1 & & 19.2 \\
\hline Least interorbital breadth $(\mathrm{mm})$ & 20.2 & & 22.5 & & 22.1 \\
\hline Palatal length $(\mathrm{mm})$ & 28.1 & & 27.1 & & 27.1 \\
\hline Post-palatal length $(\mathrm{mm})$ & 35.9 & & 35.2 & & 35 \\
\hline Foramen magnum to plane of last molars (mm) & 34.6 & & 34.5 & & 33.2 \\
\hline
\end{tabular}

$*=$ Broken skull; $* *=$ Skull only; $* * *=$ Tail only.

(MVZ 39042, 39043, 39045), 1 October 1927, 22-30 January 1928. Highway 5, between Mexicali and San Felipe [5], $32.2320^{\circ} \mathrm{N}, 115.31900^{\circ} \mathrm{W}$, $13 \mathrm{~m}$ elevation, adult female specimen (UABC 1037), 15 March 2010, measurements in Table 1. Federal Highway 50, $2.2 \mathrm{~km} \mathrm{E}[6], 32.49333^{\circ} \mathrm{N}$, $115.36792^{\circ} \mathrm{W}, 10 \mathrm{~m}$ elevation, a specimen dead on the road (F-CVUABC 180), 17 November 2012. Geotérmica Cerro Prieto, Mexicali [7], $32.39572^{\circ} \mathrm{N}, 115.27903^{\circ} \mathrm{W}, 15 \mathrm{~m}$ elevation, an adult photographed swimming in a pond ( $\mathrm{F}$ CVUABC 181-183) at 20:03, 16 September 2012.

\section{Mephitis mephitis holzneri Mearns, 1897}

Municipality of Tecate-North end of Macho Güero Valley (= Nachogüero) [8], 32.58188 $\mathrm{N}$, $116.32895^{\circ} \mathrm{W}, 1070 \mathrm{~m}$ elevation, (MVZ 39048), 22 November 1924. $2 \mathrm{~km}$ SE of Rancho San Faustino [9], $32.20913^{\circ} \mathrm{N}, 116.16386^{\circ} \mathrm{W}, 1302$ $m$ elevation, adult crossing a dirt road at 19:45 on 24 April 2013. Ejido Guadalajara, Arroyo Las Palomas (5.5 km SW from Neji) [10], $32.36816^{\circ} \mathrm{N}, 116.35406^{\circ} \mathrm{W}, 851 \mathrm{~m}$ elevation, remains of hair and skin found near the stream (F-CVUABC 184), 16 July 2013.

Municipality of Rosarito-Cantamar, $\mathrm{km} \mathrm{47}$, Federal Highway 1 [11], 32.26799 $\mathrm{N}, 116.90121^{\circ}$ $\mathrm{W}, 25 \mathrm{~m}$ elevation, a mandible found (UABC 620), 9 July 2009.

Municipality of Ensenada-Laguna Hanson, Sierra Juarez [12], $32.04687^{\circ} \mathrm{N}, 116.91164^{\circ} \mathrm{W}$, $1620 \mathrm{~m}$ elevation, 6 female specimens and 1 unknown (USNM 139724-139730), 5-9 June 1905. San Ramon, mouth of Rio Santo Domingo [13], 30.71972 ${ }^{\circ} \mathrm{N}, 116.0175^{\circ} \mathrm{W}, 12 \mathrm{~m}$ elevation, 1 female (MVZ 35438) and 3 males (MVZ 35437, 35439, 35440), 17-21 March 1921. Valle de La Trinidad [14], $31.40000^{\circ} \mathrm{N}$, $115.72305^{\circ} \mathrm{W}, 790 \mathrm{~m}$ elevation, (MVZ 37951), 22 November 1924. South end of Valle de Las Palmas [15], 32.34123 N, $116.61151^{\circ} \mathrm{W}, 307 \mathrm{~m}$ elevation, 2 specimens (MVZ 39049-39050), 13 January 1924. $16 \mathrm{~km}$ E of El Rosario [16], $30.13300^{\circ} \mathrm{N}, 115.59160^{\circ} \mathrm{W}, 245 \mathrm{~m}$ elevation, 2 specimens (SDNHM 4813, 4870), 24 May 1925. Misión Santo Domingo [17], 30.76662 ${ }^{\circ}$ N, $115.94212^{\circ} \mathrm{W}, 54 \mathrm{~m}$ elevation, an individual observed near a pool (F-CVUABC 187), 27 July 2000. Arroyo San Rafael, Mike’s Sky Ranch, Sierra San Pedro Mártir [18], 31.10972 ${ }^{\circ}$ N, $115.63472^{\circ} \mathrm{W}, 1210 \mathrm{~m}$ elevation, remains of skull and tail were collected (CVUABC 106), 19 August 2000. Cañón Agua Caliente, Valle de Guadalupe [19], $32.10443^{\circ} \mathrm{N}, 116.45368^{\circ} \mathrm{W}$, $400 \mathrm{~m}$ elevation, adult male specimen collected (UABC 107), 8 November 2001, measurements in Table 1. Federal Highway 1, near the junction to Ejido Uruapan [20], 31.61568 $8^{\circ} \mathrm{N}$, $116.44538^{\circ} \mathrm{W}, 208 \mathrm{~m}$ elevation, adult male dead on the road (F-CVUABC 163-164) on 20 April 2009. Rancho El Escondido [21], 31.90350 ${ }^{\circ} \mathrm{N}$, $116.46970^{\circ} \mathrm{W}, 575 \mathrm{~m}$ elevation, specimen (UABC 910) collected on 10 May 2009, measurements in Table 1. Camino a La Encantada [22], 31.9182 ${ }^{\circ} \mathrm{N}, 116.5212^{\circ} \mathrm{W}, 243 \mathrm{~m}$ elevation, 
skin (UABC 897), collected on 10 June 2009, measurements in Table 1. Arroyo San Carlos, near Rancho Casas Blancas [23], 31.79789 ${ }^{\circ} \mathrm{N}$, $116.49913^{\circ} \mathrm{W}, 107 \mathrm{~m}$ elevation, juvenile observed active at 22:20 on 27 July 2009. Arroyo Guadalupe, Rancho El Salto [24], 32.03659 ${ }^{\circ} \mathrm{N}$, $116.77233^{\circ} \mathrm{W}, 248 \mathrm{~m}$ elevation, several tracks observed near the arroyo (F-CVUABC 185) on 13 March 2010. El Mirador, Federal Highway $1 D$ between Tijuana-Ensenada [25], 31.98294 ${ }^{\circ}$, $116.81408^{\circ} \mathrm{W}, 255 \mathrm{~m}$ elevation, individual found dead on the road on 13 July 2010. $L a$ Salina, Federal Highway 1D between TijuanaEnsenada [26], 32.04925 ${ }^{\circ} \mathrm{N}, 116.87698^{\circ} \mathrm{W}, 29 \mathrm{~m}$ elevation, individual dead on the road on 30 July 2010. Near the entrance to Rancho El Mogor, $\mathrm{km}$ 85, Federal Highway 3 [27], $32.03864^{\circ} \mathrm{N}, 116.60531^{\circ} \mathrm{W}, 361 \mathrm{~m}$ elevation, adult specimen (F-CVUABC 168-172) found dead on the road on 7 August 2010. San Antonio de Las Minas, Federal Highway 3, kilometer marker 90.5 [28], $32.00233^{\circ} \mathrm{N}, 116.63484^{\circ} \mathrm{W}$, $320 \mathrm{~m}$ elevation, individual found dead on the road (F-CVUABC 173-175) on 7 August 2010. $\mathrm{Km}$ 106, Highway 1, access bridge to UABC [29], $31.86665^{\circ} \mathrm{N}, 116.66809^{\circ} \mathrm{W}, 15 \mathrm{~m}$ elevation, specimen dead on the road (F-CVUABC 188) on 1 February 2013. Federal Highway 1, near Las Cañadas ( $24 \mathrm{~km} S$ of Ensenada) [30], 31.65671 ${ }^{\circ} \mathrm{N}, 116.51776^{\circ} \mathrm{W}, 162 \mathrm{~m}$ elevation, individual found dead on the road (FCVUABC 178-180) on 16 April 2013. El Sauzal, near CETMAR, Federal Highway 1 [31], $31.87313^{\circ} \mathrm{N}, 116.67880^{\circ} \mathrm{W}, 9 \mathrm{~m}$ elevation, individual found dead on the road (F-CVUABC 162) on 21 May 2013. Kilometer marker 16.7, Federal Highway 3 between Ensenada-Ojos Negros [32], 31.89554 ${ }^{\circ} \mathrm{N}, 116.46890^{\circ} \mathrm{W}, 523 \mathrm{~m}$ elevation, individual dead on the road (FCVUABC 176-177) on 3 June 2013. UABC campus of Ciencia y Tecnología, Ensenada [33], $31.86450^{\circ} \mathrm{N}, 116.66726^{\circ} \mathrm{W}, 10 \mathrm{~m}$ elevation, adult female was seen with 2 broods on 4 June 2013 and adult female collected (UABC 1158) on 17 June 2013, measurements in Table 1. Federal Highway 3 between Ensenada-Ojos Negros, $200 \mathrm{~m}$ from the entrance of Rancho Agua Viva [34], $31.89862^{\circ} \mathrm{N}, 116.42661^{\circ} \mathrm{W}$, $560 \mathrm{~m}$ elevation, individual dead on the road (F-CVUABC 165-167) on 06 June 2013. Kilometer marker 19, Federal Highway 3 between Ensenada-Ojos Negros [35], $31.90005^{\circ} \mathrm{N}$, $116.44539^{\circ} \mathrm{W}, 586 \mathrm{~m}$ elevation, individual dead on the road (F-CVUABC 186) on 15 July 2013.
Kilometer marker 24, Federal Highway 3 between Ensenada-Ojos Negros [36], 31.88782 ${ }^{\circ} \mathrm{N}$, $116.40163^{\circ} \mathrm{W}, 637 \mathrm{~m}$ elevation, an individual dead on the road was seen on 15 July 2013.

\section{Concluding Comments}

The records documented herein confirm the presence of Mephitis mephitis holzneri at elevations from sea level to $1600 \mathrm{~m}$ in northwestern Baja California south to the Arroyo El Rosario, about $80 \mathrm{~km}$ south of the Arroyo Santo Domingo, which was reported as the southern limit by Huey (1964). The distribution in Baja California comprises 4 ecoregions (González-Abraham et al. 2010): Chaparral, Coastal Sage Scrub, Coastal Succulent Scrub, and the California Mountains. The striped skunk is apparently more common in riparian habitats and urban or suburban zones than in other habitats. In northeastern Baja California, M. m. estor is found mainly in association with xeric vegetation in the San Felipe Desert region and in agricultural areas and along irrigation channels of the Colorado River Delta.

We thank Enrique Sarabia and Emma Flores-Rojas for helping in the preparation of the striped skunk specimens deposited in the Mammal Collection of the Universidad Autónoma de Baja California. We also thank Chris Conroy of the Museum of Vertebrate Zoology and the Mammal Networked Information System (MaNIS) web portal, for access to the historical museum records. Philip Unitt, Scott Tremor, Michael Wall, and Margaret Dykens of the San Diego Natural History Museum, as well as 2 anonymous reviewers, made very useful comments that improved and clarified the content of the manuscript.

\section{Literature Cited}

Álvarez-Castañeda, S.T. 2000. Familia Mustelidae. Pages 731-757 in S.T. Álvarez-Castañeda and J.L. Patton, editors, Mamíferos del Noroeste de México II. Centro de Investigaciones Biológicas del Noroeste, S.C. Mexico.

BAKer, R.H. 1956. Mammals of Coahuila, Mexico. University of Kansas Publications, Museum of Natural History 9:125-335.

Feldhamer, G.A., B.C. Thompson, and J.A. Chapman. 2003. Wild mammals of North America. Biology, management, and conservation. 2nd edition. Johns Hopkins University Press, Baltimore, MD.

González-Abraham, C.E., P.P. Garcillan, E. Ezcurra, and Grupo de Trabajo Ecorregiones. 2010. 
Ecorregiones de la península de Baja California: una síntesis. Boletín de la Sociedad Botánica Mexicana 87:69-82.

Grinnell, J., J.S. Dixon, and J.M. Linsdale. 1937. Furbearing mammals of California. Their natural history, systematic status, and relations to man. University of California Press, Berkeley, CA.

HaLl, E.R. 1981. The mammals of North America. Ronald Press Company, New York, NY.

Hamilton, W.J., Jr., and J.O. Whitaker Jr. 1979. Mammals of the eastern United States. Cornell University Press, Ithaca, NY.

HowELL, W.T. 1901. Revision of the skunks of the genus Chincha. North American Fauna 20:1-45.

Huey, L.M. 1964. The mammals of Baja California, Mexico. Transactions of the San Diego Society of Natural History 13(7):85-168.

Mearns, E.A. 1897. Preliminary diagnoses of new mammals of the genera Mephitis, Dorcelaphus and
Dicotyles, from the Mexican border of the United States. Proceedings of the U.S. National Museum 20:467-471.

Nelson, E.W. 1930. Wild animals of North America. Intimate studies of big and little creatures of the mammal kingdom. National Geographic Society, Washington, DC.

Reid, F., and K. Helgen. 2008. Mephitis mephitis. In: IUCN Red List of Threatened Species. Version 2012.2. [Accessed 10 May 2013]. Available from: http://www.iucnredlist.org

VerTs, B.J. 1967. The biology of the striped skunk. University of Illinois Press, Urbana, IL.

Wade-Smith, J., AND B.J. VerTs. 1982. Mephitis mephitis. Mammalian Species 173:1-7.

Received 12 November 2013 Accepted 17 October 2014 